\title{
Dopamine D2 Long Receptor-Deficient Mice Display Alterations in Striatum-Dependent Functions
}

\author{
Yanyan Wang, ${ }^{1}$ Rong Xu, ${ }^{1}$ Toshikuni Sasaoka, ${ }^{2}$ Susumu Tonegawa, ${ }^{3}$ Mei-Ping Kung, ${ }^{4}$ and \\ Emma-Betty Sankoorikal ${ }^{1}$
}

Departments of ${ }^{1}$ Pharmacology and ${ }^{4}$ Radiology, University of Pennsylvania School of Medicine, Philadelphia, Pennsylvania 19104-6084, 2Division of Cortical Function Disorders, National Institute of Neuroscience, 4-1-1 Ogawahigashi, Kodaira, Tokyo 187-8502, Japan, and ${ }^{3}$ Howard Hughes Medical Institute and Department of Biology, Massachusetts Institute of Technology, Cambridge, Massachusetts 02139

\begin{abstract}
The dopamine D2 receptor (D2) system has been implicated in several neurological and psychiatric disorders, such as schizophrenia and Parkinson's disease. There are two isoforms of the D2 receptor: the long form (D2L) and the short form (D2S). The two isoforms are generated by alternative splicing of the same gene and differ only by 29 amino acids in their protein structures. Little is known about the distinct functions of either D2 isoform, primarily because selective pharmacological agents are not available. We generated D2L receptor-deficient (D2L-/-) mice by making a subtle mutation in the $\mathrm{D} 2$ gene. D2L $-/-$ mice (which still express functional D2S) displayed reduced levels of locomotion and rearing behavior. Interestingly, haloperidol produced significantly less catalepsy and inhibition of locomotor activity in D2L $-/-$ mice. These findings suggest that D2L and
\end{abstract}

D2S may contribute differentially to the regulation of certain motor functions and to the induction of the extrapyramidal side effects associated with the use of typical antipsychotic drugs (e.g., haloperidol). Quinpirole induced a similar initial suppression of locomotor activity in both $\mathrm{D} 2 \mathrm{~L}-/-$ and wild-type mice. In addition, the D2S receptor in the mutant mice functioned approximately equally well as did D2L as an impulse-modulating autoreceptor. This suggests that the functions of these two isoforms are not dependent on the formation of receptor heterodimers. Our findings may provide novel information for potentially developing improved antipsychotic drugs.

Key words: dopamine D2L receptor; knock-out mice; locomotion; catalepsy; autoreceptor; haloperidol; D2S receptor
Alterations in the dopamine D2 receptor (D2) system have been implicated in a variety of neurological and psychiatric disorders, including schizophrenia, Parkinson's disease, Huntington's disease, attention-deficit hyperactive disorder, and drug addiction (Sibley et al., 1993; Graybiel, 1995; Jaber et al., 1996; Nestler and Aghajanian, 1997; Koob et al., 1998). Parkinsonian patients exhibit deficits in motor function, which are attributed to the degeneration of dopaminergic neurons in the substantia nigra (SN) (Hornykiewicz, 1966). Schizophrenic patients exhibit psychotic symptoms, which may partially result from dysfunction of the mesocortical and hippocampal dopamine (DA) systems (Carlsson and Carlsson, 1990; Jaskiw and Weinberger, 1992). The drugs typically used to treat schizophrenia and Parkinson's disease are D2 antagonists or agonists, respectively, suggesting that the D2 receptor plays an important role in these two neuropsychiatric diseases.

Two isoforms of the D2 receptor [the long form (D2L) and the short form (D2S)] have been identified (Bunzow et al., 1988; Dal Toso et al., 1989; Giros et al., 1989; Monsma et al., 1989; Chio et al., 1990; Mack et al., 1991). The D2L and D2S receptors are generated from the same gene by alternative splicing. The $\mathrm{D} 2 \mathrm{~L}$ receptor has

Received May 22, 2000; revised Aug. 18, 2000; accepted Sept. 1, 2000.

This work was supported by grants to Y.W. from the National Alliance for Research on Schizophrenia and Depression, March of Dimes Birth Defects Foundation, Thomas and Jeannette McCabe Fund, University of Pennsylvania Research Foundation, and Whitehall Foundation and by grants to S.T. from the National Institutes of Health (NS 32925-07) and the Shionogi Institute for Medical Sciences. The process of making D2L knock-out mice was conducted in part at Dr. Tonegawa's laboratory. I (Y.W.) would like to thank many members in Dr. Tonegawa's laboratory for their suggestions and friendship and give special thanks to Drs. T. Iwasato, M. Wu, A. Ebralidze, and H. Prosser. We thank Dr. G. K. Aghajanian for useful suggestions, Dr. F. Jin for contribution to the immunohistochemical analysis, C. Hou and K.-L. Vukhac for technical assistance, Dr. D. Beitner-Johnson for editorial assistance, and J. Phillips for miscellaneous help.

Correspondence should be addressed to Dr. Yanyan Wang, Department of Pharmacology, University of Pennsylvania School of Medicine, M102 John Morgan, 3620 Hamilton Walk, Philadelphia, PA 19104-6084. E-mail: yywang@pharm.med.upenn.edu. Copyright (C) 2000 Society for Neuroscience $0270-6474 / 00 / 208305-10 \$ 15.00 / 0$ a 29 amino acid insertion in the third cytoplasmic loop of the protein, and this insertion is absent in the D2S receptor. The third intracellular loop of G-protein-coupled receptors (including DA receptors) has been shown to be critical for their interactions with intracellular effectors (O'Dowd et al., 1988). In transfected cell lines, it has been shown that D2L and D2S are coupled to, or display differential affinities for, different inhibitory G-proteins (Dal Toso et al., 1989; Senogles, 1994; Guiramand et al., 1995; Boundy et al., 1996). The two isoforms coexist in all brain tissue analyzed; however, the expression ratio of D2L versus D2S varies considerably from region to region (Mack et al., 1991; Neve et al., 1991). The differences in protein structure, expression pattern, and interaction with intracellular effectors suggest that the two D2 isoforms may have differential functions. In addition, the etiology of motor deficits and psychoses involves different brain regions, and the expression ratio of $\mathrm{D} 2$ isoforms differs in these regions. Thus, there is a possibility that D2L and D2S may play differential roles in defining the therapeutic ratio of antipsychotic and/or antiparkinsonian drugs.

The lack of an isoform-selective pharmacological agent has hampered the progress toward understanding the specific function of D2L and D2S in the mammalian CNS. Our strategy for addressing this issue is to generate mutant mice expressing only a single D2 isoform by using gene-targeting technology. Such mutant mice serve as unique model systems for dissecting the function of either D2 isoform at the molecular, cellular, and systems levels in the CNS. As an initial step, we created mice lacking D2L but expressing functional D2S by making a subtle mutation in the D2 gene. The present study was undertaken to determine whether there are alterations in basal ganglia-dependent functions in D2L receptordeficient (D2L-/-) mice. D2L comprises $\sim 80 \%$ of the total D2 receptor in the whole brain (including $\mathrm{SN}$ ) of wild-type (WT) mice, and the relative proportion of $\mathrm{D} 2 \mathrm{~L}$ is even higher in the striatum ( $\sim 90 \%$ of total D2) (Mack et al., 1991) (for our observations, see Fig. $1 C$ ). In contrast, D2S is the only D2 receptor expressed in 
D2L-/- mice. Thus, biochemical, behavioral, and physiological analyses of D2L-/- mice may reveal novel information concerning the potential functional roles of D2L as well as D2S.

\section{MATERIALS AND METHODS}

Subtle mutation of the D2 receptor gene to generate D2L-deficient mice. The mouse D2 gene containing exons 3-8 was cloned from a mouse 129/SV genomic DNA library. The targeting vector was constructed using a $15.5 \mathrm{~kb}$ mouse genomic D2 fragment in which exon 6 was replaced by a PGK-neo cassette (neo). In addition, neo was flanked by loxP on both sides (should neo disrupt the transcription process, the Cre recombinase system is used to remove neo). The targeting vector was transfected into embryonic stem (ES) cells (J1 from 129/terSv) by electroporation (Silva et al., 1992). Correctly targeted ES clones were identified by Southern blot analysis using probes $\mathrm{A}$ and $\mathrm{B}$ (see Fig. 1) and microinjected into C57BL/6 blastocysts to produce chimeric mice. Chimeric mice were crossed with C57BL/6 mice (Taconic, Germantown, NY) to produce heterozygous mice. Heterozygous mice (D2L+/-; F1) were then intercrossed to produce homozygous mice $(\mathrm{F} 2)$ on a hybrid background $(129 /$ terSv $\times$ C57BL/6). To minimize the variation of genetic background, D2L $+/-$ mice were also backcrossed to the C57BL/6 strain for five generations to establish an incipient congenic B6 line (N5/B6) (Banbury Conference on Genetic Background in Mice, 1997).

Reverse transcriptase-PCR. Total RNA isolated from the striatum of D2L-/- or WT littermates was reverse-transcribed into cDNA using oligonucleotide primers complementary to exon 8 of the D2 gene. The resulting cDNA was used in a PCR reaction with oligonucleotide primers complementary to exon 5 [5'-(d GAGTGTATCATTGCCAACCCT-

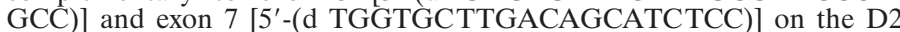
gene. Conditions for the PCR were $94^{\circ} \mathrm{C}$ for $30 \mathrm{sec}, 60^{\circ} \mathrm{C}$ for $1 \mathrm{~min}$, and $72^{\circ} \mathrm{C}$ for 3.5 min for 35 cycles. Total striatal RNA was obtained from three or four mice for each genotype on two separate occasions. The experiments were repeated five times.

Receptor autoradiography. Three $\mathrm{WT}$ and three $\mathrm{D} 2 \mathrm{~L}-/-$ mice were killed by cervical dislocation, and the brains were removed. The brains were placed in OTC embedding medium (Miles, Elkhart, IN) and frozen in powdered dry ice. Coronal sections $(20 \mu \mathrm{m}$ thickness) were cut on a cryostat microtome (Hacker Instruments, Fairfield, NJ) and thaw-mounted onto gelatin-coated glass slides. Brain sections were obtained from mouse forebrain, which corresponded to plates 19-24 (Franklin and Paxinos, 1996). Thus, the sections included cerebral cortex, caudate-putamen, nucleus accumbens, olfactory tubercle and the islands of Calleja. The sections were desiccated at $4^{\circ} \mathrm{C}$ for $3 \mathrm{hr}$ and then kept at $-20^{\circ} \mathrm{C}$ until use. Before the assay, sections were thawed, dried at room temperature, and preincubated for $30 \mathrm{~min}$ at room temperature in buffer containing $50 \mathrm{mM}$ Tris-HCl, $\mathrm{pH}$ 7.0. After preincubation, the sections were labeled in coplin jars with $\left.0.05 \mathrm{nM}{ }^{125} \mathrm{I}\right] \mathrm{NCQ} 298$ (for dopamine D2 and D3 receptors) and $0.2 \mathrm{~nm}\left[{ }^{125} \mathrm{I}\right] 5$-OH-PIPAT (for the dopamine D3 receptor). [ $\left.{ }^{125} \mathrm{I}\right] \mathrm{NCQ} 298$ labeling was performed in buffer containing $50 \mathrm{~mm}$ Tris- $\mathrm{HCl}, \mathrm{pH} 7.4$, and $120 \mathrm{~mm} \mathrm{NaCl}$ at room temperature for $120 \mathrm{~min}$, followed by two $20 \mathrm{~min}$ washes at $4^{\circ} \mathrm{C}$. Nonspecific binding was determined in the presence of $2 \mu \mathrm{M}$ (+)-butaclamol. [ $\left.{ }^{125} \mathrm{I}\right] 5-\mathrm{OH}-\mathrm{PIPAT}$ labeling was performed in the buffer containing $50 \mathrm{~mm}$ Tris-HCl, $\mathrm{pH} 6.8,2 \mathrm{~mm}$ EDTA, and $120 \mathrm{~mm} \mathrm{NaCl}$ at room temperature for $120 \mathrm{~min}$, followed by two washes, each $1.5 \mathrm{hr}$ in duration at $4^{\circ} \mathrm{C}$. Nonspecific binding was defined in the presence of $1 \mu \mathrm{M}$ $( \pm) 7-\mathrm{OH}-\mathrm{DPAT}$. After the wash procedure was completed, the sections were dipped in ice-cold distilled water to remove buffer salts before drying with a stream of cold air. Dried sections were exposed to either Kodak X-OMAT AR or DuPont Cronex MRF 34 films for $18 \mathrm{hr}$, and the analysis of the autoradiograms was performed using a computer-based image analysis system (NIH Image, version 1.61). The binding sites were expressed in units of optical density in the linear range.

Receptor binding assays. Saturation binding assays of [ $\left.{ }^{3} \mathrm{H}\right] \mathrm{YM}-09151-2$ were performed as described previously with slight modifications $(\mathrm{Xu}$ et al., 1996; Zhang et al., 1996). Briefly, striatal tissue was homogenized in ice-cold buffer (15 mM Tris-HCl and $5 \mathrm{~mm}$ EDTA, $\mathrm{pH}$ 7.4). The homogenate was centrifuged twice at $35000 \times g$ for $40 \mathrm{~min}$ at $4^{\circ} \mathrm{C}$ and then stored at $-20^{\circ} \mathrm{C}$. The protein concentration of membrane homogenates was determined using the Bradford reagent (Sigma, St. Louis, MO). Aliquots of striatal membrane homogenates containing $60 \mu \mathrm{g}$ of protein were incubated in duplicate with [ $\left.{ }^{3} \mathrm{H}\right] \mathrm{YM}-09151-2$ (specific activity, $85.5 \mathrm{Ci} /$ mmol; NEN Life Science Products, Boston, MA) in a volume of $1 \mathrm{ml}$ at $25^{\circ} \mathrm{C}$ for $40 \mathrm{~min}$. Concentrations of $\left[{ }^{3} \mathrm{H}\right] \mathrm{YM}-09151-2$ ranging from 0.01 to $0.8 \mathrm{~nm}$ were used. The incubations were terminated by rapid filtration through Whatman GF/B filters. The filters were rinsed three times with 4 $\mathrm{ml}$ of cold binding buffer ( $50 \mathrm{~mm}$ Tris- $\mathrm{HCl}, 120 \mathrm{~mm} \mathrm{NaCl}, 5 \mathrm{~mm} \mathrm{KCl}, 1.5$ $\mathrm{mM} \mathrm{CaCl}, 5 \mathrm{mM} \mathrm{MgCl}$, and $0.1 \%$ ascorbic acid, $\mathrm{pH}$ 7.4). Nonspecific binding was defined in the presence of spiperone $(5 \mu \mathrm{M})$. Striatal tissue from four mice of each genotype was used for each experiment. Saturation binding assays of $\left[{ }^{3} \mathrm{H}\right] \mathrm{SCH} 23390$ were performed using a similar method except that aliquots of striatal membrane homogenates containing $60 \mu \mathrm{g}$ of protein were incubated in duplicate with $\left[{ }^{3} \mathrm{H}\right] \mathrm{SCH} 23390$ (specific activity, $86 \mathrm{Ci} / \mathrm{mmol}$; Amersham Life Science, Arlington Heights, IL) in a volume of $1 \mathrm{ml}$ at $30^{\circ} \mathrm{C}$ for $60 \mathrm{~min}$. Nonspecific binding was defined in the presence of $(+)$-butaclamol $(10 \mu \mathrm{M})$. Binding data were analyzed using the Prism program (Graph Pad Software, San Diego, CA). Spiperone and (+)butaclamol were obtained from Research Biochemicals (Natick, MA).

Behavioral studies. Male mice (3-7 months old) on either the hybrid (mainly F2) or congenic B6 genetic background (N5/B6) were used. Animals were maintained on a $12 \mathrm{hr}$ light/dark cycle (7:00 A.M./7:00 P.M.). Behavioral experiments were conducted in an isolated room under dim light between 10:00 A.M. and 5:00 P.M. Animal behaviors were recorded with a video camera. All experiments were conducted blind in the sense that the experimenters had no knowledge of the genotypes and the treatment of the mice.

For the open-field test, a mouse was placed in the center of a Plexiglas chamber $(50 \times 50 \mathrm{~cm}$; divided by lines on the floor into 25 equal squares $)$. Nine inner squares were defined as the central area. Locomotion (ambulation) was measured as the number of squares crossed by the mouse within 5 or 10 min (Baik et al., 1995). Rearing responses (raising of both forefeet and extension of the body) were monitored at the same time.

For measuring the activity of animals during a $24 \mathrm{hr}$ period, mice housed individually in standard plastic cages were brought to the room $24 \mathrm{hr}$ before testing. The mouse cage was positioned in an automated open-field activity monitor, consisting of an open-field chamber $(17 \times 17$ inch) with three 16-beam I/R arrays and 48-channel control (MED Associates, Inc.). Data were collected continuously by the computer for $24 \mathrm{hr}$.

Spontaneous immobility was measured by placing the mice on a ring that is $5.5 \mathrm{~cm}$ in diameter and $16 \mathrm{~cm}$ above the base (the ring test) (Pertwee, 1972). The ring test was chosen because it has been widely used in measuring the spontaneous (or basal) immobility of mutant mice (Xu et al., 1994), including D2-null knock-out mice (Baik et al., 1995). The length of time that animals remained immobile on the ring was recorded, with a cutoff time of $3 \mathrm{~min}$. On the basis of our pilot study, each mouse was given a maximum of two consecutive trials in the ring test to minimize the possibility that animals did not perform a test by chance. The best performance (i.e., the trial with the longest duration of immobility) was used in the data analysis.

The elevated zero-maze was made from a dark gray polyvinyl chloride (PVC) annular platform $(60 \mathrm{~cm}$ in diameter and $7 \mathrm{~cm}$ in width) elevated 60 $\mathrm{cm}$ above the floor. The zero-maze is divided into four equal sectors: two opposite open sectors and two opposite closed sectors. The two closed sectors are enclosed by dark gray PVC walls $(19 \mathrm{~cm}$ high $)$ on both the inner and outer edges of the platform. For testing, a mouse was initially placed on an open sector just in front of a closed sector and left for 5 min (Konig et al., 1996). The analysis of the data was performed according to the standard methods described by Shepherd et al. (1994) and Konig et al. (1996), using the following criteria: (1) The percentage of time in the open areas. This is the time that animals spent in the open sectors with all four paws divided by the total testing time. (2) General activity. This activity was measured as the number of different sectors crossed by animals. (3) Head dips. The number of head dips was counted when animals looked over or down the edge of the runway. (4) Stretched attend postures. The number of stretched attend postures was counted when animals, on the closed sector side at the interface between the closed and open sectors, displayed an elongated body posture stretched toward the open sector. The zero-maze, a modified version of the plus-maze, is a standard method for measuring the anxiety of rodents. The merits of this method as compared with the plus-maze have been reviewed extensively by Shepherd et al. (1994).

Catalepsy induced by haloperidol was measured by placing the forepaws of the mice on a 5-cm-high horizontal bar (the bar test) (Ushijima et al., 1995). The length of time that animals held the bar without any voluntary movement was recorded, with a cutoff time of $3 \mathrm{~min}$. The bar test was chosen because it is commonly used in studying the effects of haloperidol on the cataleptic behavior of rodents. Our pilot study indicated that most of the wild-type mice exhibited maximal catalepsy (i.e., $3 \mathrm{~min}$ of immobility) in response to haloperidol treatment only after repeated trials. Thus, each mouse was given a maximum of five consecutive trials to exhibit haloperidol-induced catalepsy. If a mouse remained immobile for $180 \mathrm{sec}$ (cutoff time) on the bar at any given trial, the mouse was removed from the testing device and returned to a normal mouse cage. All mice received vehicle injection a few days before drug treatment to minimize the injection or vehicle effect. A few days later, mice received haloperidol or the second vehicle injection (see Fig. $8 B$ ). Some mice on a hybrid background (one $+/+$ and six $-/-$ mice) exhibited significant immobility in response to vehicle injection in the bar test. These animals were therefore excluded from further testing because they had showed immobility previously for a duration close to the cutoff time and no drug-induced catalepsy could be detected within the 3 min testing time. Importantly, none of the WT and $\mathrm{D} 2 \mathrm{~L}-/-$ mice on a congenic B6 background displayed any immobility in response to vehicle injection, and none of these animals were excluded from the study.

Haloperidol (Research Biochemicals) was dissolved in $0.9 \% \mathrm{NaCl}$ containing $0.03-0.1 \%$ lactic acid and adjusted to $\mathrm{pH} 5.2$ by adding $\mathrm{NaOH}$. The vehicle solution injected was $0.9 \% \mathrm{NaCl}$ containing $0.03-0.1 \%$ lactic acid. $(-)$-Quinpirole (Research Biochemicals) was dissolved in $0.9 \%$ saline. Drugs were administrated intraperitoneally, and the injection volume was $5 \mathrm{ml} / \mathrm{kg}$ of body weight. Drug doses were administrated in ascending order, starting with the respective vehicle injection, with 3-7 d between injections or doses to avoid potential carryover effects. Some animals received only one dose of drugs, some received two different doses, and some received 
A
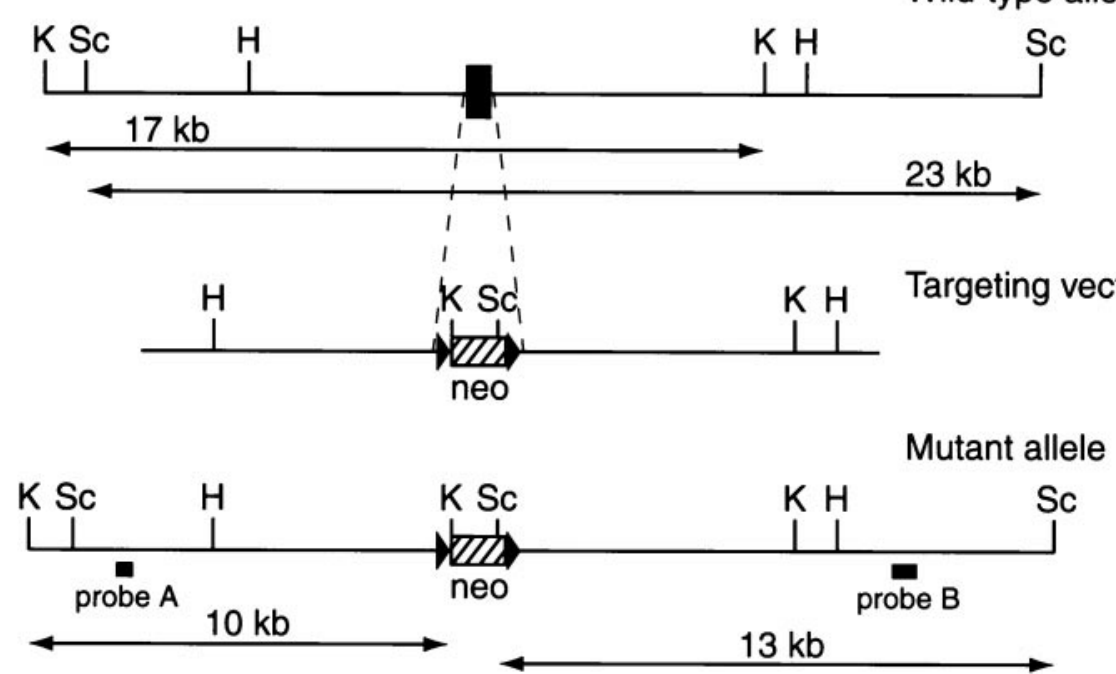

B
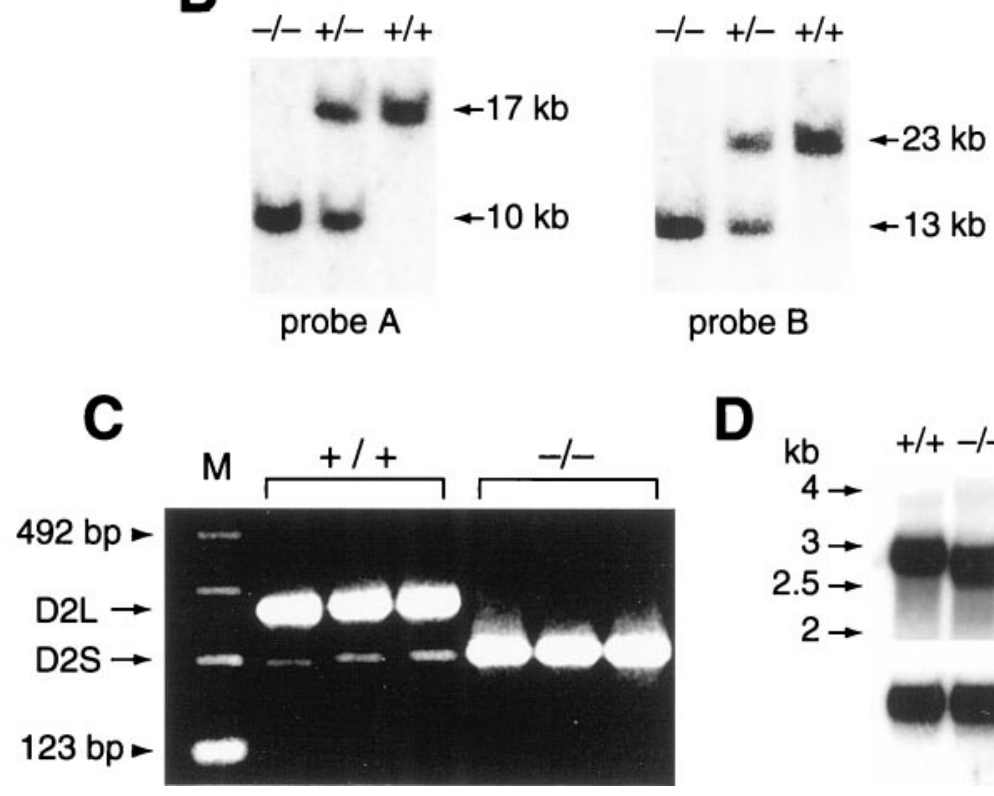

D

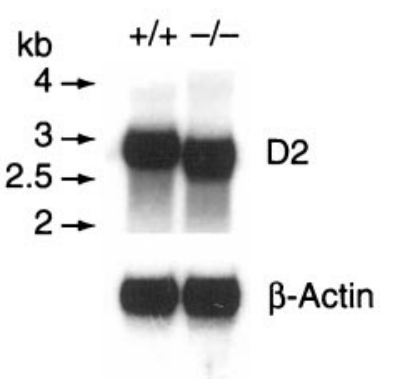

Figure 1. Targeted disruption of the D2L gene. $A$, Targeting vector. For gene targeting of the D2L locus, exon 6 (solid box, enlarged for visualization) was replaced by a PGK-neo cassette that was flanked by loxP (arrowheads). H, HindIII; K, KpnI; Sc, ScaI. B, Southern blot analysis of genomic DNA from mouse tails (-/-, homozygote; $+/-$, heterozygote; $+/+$, wild type). Tail DNAs were either digested with KpnI and hybridized with the external probe A or digested with $S c a \mathrm{I}$ and hybridized with the external probe B. $C$, Detection of two forms of D2 mRNA by RT-PCR. PCR products, differing by 87 base pairs and corresponding to the alternatively spliced isoforms of D2 mRNAs, were shown (numbering from the left) in lanes 2-4 (+/+ mice; $235 \mathrm{bp}, \mathrm{D} 2 \mathrm{~S} ; 322 \mathrm{bp}, \mathrm{D} 2 \mathrm{~L})$ and in lanes 5-7 $(-1-$ mice $)$. The size marker $(M)$ was a 123 bp DNA ladder (lane 1; Life Technologies, Gaithersburg, MD). $D$, Northern blot analysis of $\mathrm{D} 2$ receptor RNA levels in the striatum of $+/+$ (lane 1, left) and -/- (lane 2) mice. The probe used was a DNA fragment complementary to exon 7 of the D2 gene and thus hybridized to RNA from both WT and D2L-/- mice. Total striatal RNA used for Northern analysis was obtained from three to four mice for each genotype on two separate occasions. The data were quantified with densitometric analysis using a scanner (UMAX Astra 2400S) and the IQ Mae program. The data were repeated four times. After normalization to the intensity of $\beta$-actin, the amount of D2 mRNA from $+/+(1.04 \pm 0.04 \mathrm{U} ; n=4)$ was not significantly different from the amount of D2 mRNA from - $1-$ $(1.06 \pm 0.05 \mathrm{U} ; n=4 ; p>0.8$, Student's $t$ test). Note that the D2 mRNA from mutant mice was present at the predicted smaller size, which is comparable with the size of D2S mRNA. The size marker indicated by the arrows was Millennium RNA size marker (Ambion, Austin, TX). $\beta$-Actin RNA levels were simultaneously monitored as an internal control. repeated vehicle injection. Groups of animals were randomly assigned, depending on the availability of animals at the time of the experiments. The effects of haloperidol on catalepsy or locomotion were tested $30 \mathrm{~min}$ after the injection. The effect of quinpirole on locomotion was tested 10 min after the injection.

The protocol used for the rotarod test in mice was that recommended by the manufacturer (Basile, Comerio, Italy), using the Rotarod Treadmill with accelerating speed (Basile; Stoelting). It has been reported that an accelerating speed in this test reduces the variability of the data (Jones and Roberts, 1968). The rotation speed of the rod was increased from 2 to 20 rpm within 5 min, which was also the cutoff time. A timer automatically recorded the length of time each mouse stayed on the rotating rod. Mice were tested on 2 consecutive days. On day 1, each mouse was given three trials, with an interval of $\sim 2.25 \mathrm{hr}$ between each trial. On day 2 , the test was stopped after the second trial because the mice had reached and maintained their ceiling performance.

Electrophysiological recordings. The methods for preparation and maintenance of brain slices were similar to those described previously (Wang and Aghajanian, 1990; Stevens and Wang, 1994). Briefly, coronal slices containing the substantia nigra $(\sim 300 \mu \mathrm{m})$ were cut with a vibratome (WPI, Sarasota, FL). The slices were then incubated in artificial CSF (ACSF) at room temperature for at least $1 \mathrm{hr}$. A single slice was transferred to a submerged type of recording chamber with continuous perfusion of ACSF at $\sim 32^{\circ} \mathrm{C}$. The ACSF, equilibrated with $95 \% \mathrm{O}_{2} / 5 \% \mathrm{CO}_{2}$, was composed of (in $\mathrm{mM}$ ): $\mathrm{NaCl} 126, \mathrm{KCl} 5, \mathrm{NaH}_{2} \mathrm{PO}_{4} 1.25$, glucose 10, $\mathrm{NaHCO}_{3} 26, \mathrm{MgSO}_{4} 1.3$, and $\mathrm{CaCl}_{2}$ 2.4. The zona compacta of the substantia nigra ( $\mathrm{SNc}$ ) was identified according to Franklin and Paxinos (1996). Dopaminergic neurons were identified on the basis of their electrophysiological characteristics (Grace and Bunney, 1983) and response to dopamine. Spontaneous extracellular potentials of dopaminergic neurons were recorded by means of electrodes filled with ACSF. The electrophysiological experiments were conducted using an Axoclamp-2B (Axon Instruments, Foster City, CA). Data were collected and analyzed using pClamp6 program (Axon Instruments). (-)-Sulpiride was obtained from Research Biochemicals, and dopamine was from Sigma.

\section{RESULTS}

\section{Generation of dopamine D2L receptor-deficient mice}

D2L-deficient mice were produced by deleting a small region of the D2 gene that contains the exon $6(87 \mathrm{bp})$ encoding the D2L insert region of 29 amino acids in the third intracellular loop (Fig. $1 A$ ). In this way, the gene fragment encoding the D2S receptor remained intact. Homozygous mice were identified by Southern blot analysis (Fig. 1B). D2L mRNA was not detectable by reverse transcriptasePCR (RT-PCR) analysis in homozygous mice (Fig. 1C). In con- 
A
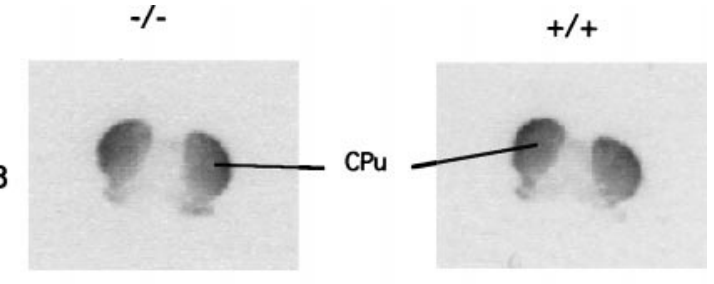

B

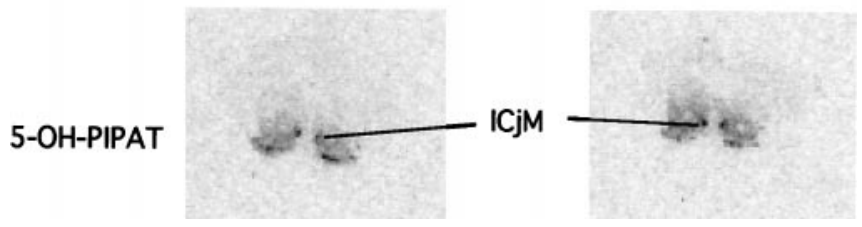

Figure 2. Representative autoradiographic localizations of [ $\left.{ }^{125} \mathrm{I}\right] \mathrm{NCQ} 298$ $(A)$ and $\left[{ }^{125} \mathrm{I}\right] 5-\mathrm{OH}-\mathrm{PIPAT}(B)$ binding in WT $(+/+)$ and $\mathrm{D} 2 \mathrm{~L}-/-(-/-)$
mice. $\left[{ }^{125} \mathrm{I}\right] \mathrm{NCQ} 298$ revealed $\mathrm{D} 2$ and $\mathrm{D} 3$ receptor binding sites, and $\left[{ }^{25} \mathrm{I}\right] 5-$ OH-PIPAT, under these assay conditions, only labeled D3 receptor binding sites (Kung et al., 1994; Vessotskie et al., 1997b). Both D2 and D3 binding sites were present in $+/+$ and $-/-$ animals. There was no significant difference in the number of sites labeled with either ligand between $+/+$ and $-/-$ mice. $C P u$, Caudate-putamen, which contains mainly the D2 receptor (Civelli et al., 1993); ICjM, major islands of Calleja, which contain the D3 receptor but not other D2-like receptors (Civelli et al., 1993).

trast, D2S mRNA in D2L-/- mice was clearly present and expressed at an increased level (Fig. 1C). Northern blot analysis further suggested that D2S was upregulated to a level similar to that of total D2 mRNA in WT mice. Indeed, the density of D2 receptor was similar between $\mathrm{D} 2 \mathrm{~L}-/-$ mice and their normal littermates in various brain regions, as determined by immunohistochemistry with a specific D2 receptor antibody (data not shown) and receptor autoradiography with $\left[{ }^{125} \mathrm{I}\right] \mathrm{NCQ} 298$, a ligand with high affinity for the D2 and D3 receptors (Vessotskie et al., 1997a). There was no significant difference in the total number of binding sites labeled with $\left[{ }^{125} \mathrm{I}\right] \mathrm{NCQ} 298$ (D2 + D3) between WT and $\mathrm{D} 2 \mathrm{~L}-/-$ mice $(84.78 \pm 11.63$ and $75.43 \pm 7.43$, respectively; $p>$ 0.16 , Student's $t$ test) (Fig. $2 A$ ). Similarly, the D3 binding sites labeled with $\left[{ }^{125} \mathrm{I}\right] 5-\mathrm{OH}-\mathrm{PIPAT}$, which selectively labeled the D3 receptor under the assay conditions described in Materials and Methods, were not affected in D2L $-/-$ mice $(154.0 \pm 11.54$ and $153.6 \pm 17.24$ for $+/+$ and $-/-$ mice, respectively; $p>0.11$ ) (Fig. $2 B$ ). Previous studies have shown that the expression and/or sensitivity of the D3 and D4 receptors are not affected in D2 receptornull knock-out mice that lack both D2 isoforms (Baik et al., 1995; Kelly et al., 1998). Therefore, it is unlikely that the potential alteration in D3 would be a major compensatory mechanism in the more subtle D2L-/- mutant mice.

To confirm further the levels of the D2 receptor in the mutant mice, we performed saturation binding assays of $\left[{ }^{3} \mathrm{H}\right] \mathrm{YM}-09151-2$ (a standard D2 radioligand and D2 antagonist) using striatal tissue. Radioligand binding assays are a quantitative method to determine receptor numbers. Striatum was chosen because D2L is the predominant D2 isoform in this region ( $\sim 90 \%$ of total D2) in WT mice, whereas D2S is the only $\mathrm{D} 2$ isoform in $\mathrm{D} 2 \mathrm{~L}-/-$ mice (see Fig. $1 C$ ). The number of D2 receptor sites ( $B_{\max }$ values) of YM09151-2 was not significantly different between WT (458.2 \pm 34.2 $\mathrm{fmol} / \mathrm{mg}$ of protein; $n=4$ independent experiments) and D2L-/(422.5 $\pm 10.0 \mathrm{fmol} / \mathrm{mg}$ of protein; $n=4$ independent experiments) mice (Fig. $3 A)(p>0.35$, Student's $t$ test). In contrast, the affinities $\left(K_{d}\right.$ values) of $\left[{ }^{3} \mathrm{H}\right] \mathrm{YM}-09151-2$ were significantly different between WT $(81.3 \pm 0.7 \mathrm{pm})$ and D2L-/- (125.6 $\pm 7.3 \mathrm{pm} ; p<$ $0.005)$ (Fig. $3 A$ ), values that are comparable with the $K_{d}$ values of YM-09151-2 for D2L and D2S in recombinant cell lines (Vile et al., 1995). Together, these data further indicate that D2S is upregulated and expressed on the cell surface in the mutant mice. It has been reported that in the absence of both D2 isoforms, D1 receptor density is either unchanged (Baik et al., 1995) or reduced (Kelly et
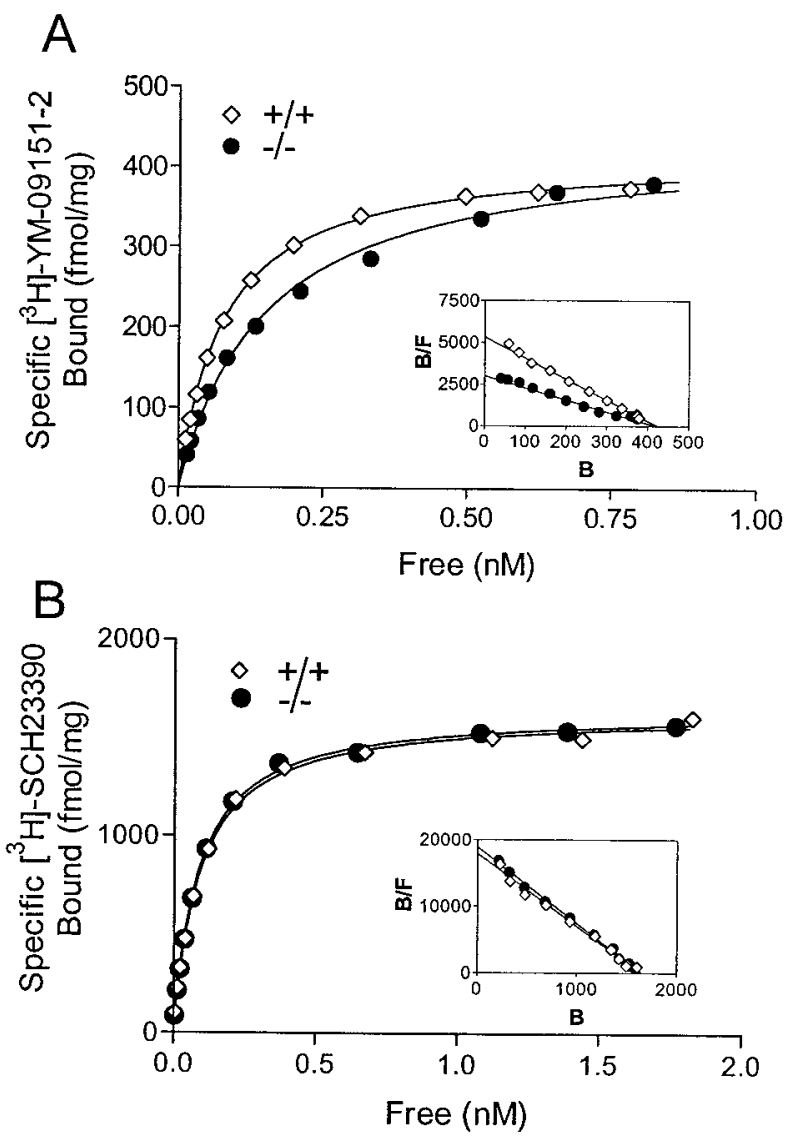

Figure 3. D2 and D1 ligand binding assays. $A$, Saturation binding curve of $\left[{ }^{3} \mathrm{H}\right] \mathrm{YM}-09151-2$ to the D2 receptor in striatal membranes from $+1+$ (open diamonds) and $-/-$ (solid circles) mice. Inset, A Scatchard transformation of the data. The fit lines were created from $K_{d}$ and $B_{\max }$ values determined by nonlinear regression. The data shown are from a single representative experiment. B, Saturation binding curve of $\left[{ }^{3} \mathrm{H}\right] \mathrm{SCH} 23390$ to the D1 receptor in striatal membranes. Inset, A Scatchard transformation of the data. $K_{d}$ values of $\left[{ }^{3} \mathrm{H}\right] \mathrm{SCH} 23390$ were $93.1 \pm 3.3 \mathrm{pM}$ for $+/+(n=3$ experiments) and $101.6 \pm 7.7 \mathrm{pM}$ for $-/-(n=3)(p>0.3$, Student's $t$ test $)$. $B_{\max }$ values of $\left[{ }^{3} \mathrm{H}\right] \mathrm{SCH} 23390$ were $1657.3 \pm 37.2 \mathrm{fmol} / \mathrm{mg}$ of protein for $+/+$ and $1594.3 \pm 27.1 \mathrm{fmol} / \mathrm{mg}$ of protein for $-/-(p>0.2)$. The data shown are from a single representative experiment. $B$, Bound; $F$, free.

al., 1998). To determine whether the levels of the D1 receptor are altered in the absence of D2L, we performed saturation binding assays of $\left[{ }^{3} \mathrm{H}\right] \mathrm{SCH} 23390$ using striatal tissue. There were no significant differences either in the affinity or in the number of D1 receptor sites in D2L-/- versus WT mice (Fig. $3 B$ ). Taken together, these data suggest that the possible alterations in other DA receptor systems are negligible in $\mathrm{D} 2 \mathrm{~L}-/-$ mice.

D2-null knock-out mice have been reported to exhibit stunted growth and low fertility (Baik et al., 1995; Yamaguchi et al., 1996), to have a darkened coat color (Yamaguchi et al., 1996; Kelly et al., 1997), or to have a skewed Mendelian genotype ratio of -/mice (Kelly et al., 1997). In contrast to these observations, D2L-/- mice had normal fertility and body weight, in comparison with WT mice (examined up to the age of 7 months). Homozygous mice were obtained with Mendelian frequency and appeared healthy. The coat color of $\mathrm{D} 2 \mathrm{~L}-/-$ mice was indistinguishable from that of their normal littermates. Examination of serial brain sections revealed no gross neuroanatomical abnormalities. Taken together, the data suggest that any potential alterations in growth and development of D2L-/- mice (which still express the D2S isoform) are less severe than are those of D2-null knock-outs (which lack both D2L and D2S isoforms). This lack of gross abnormalities enabled us to study the role of the D2L isoform in behavioral and physiological responses in adult animals. 

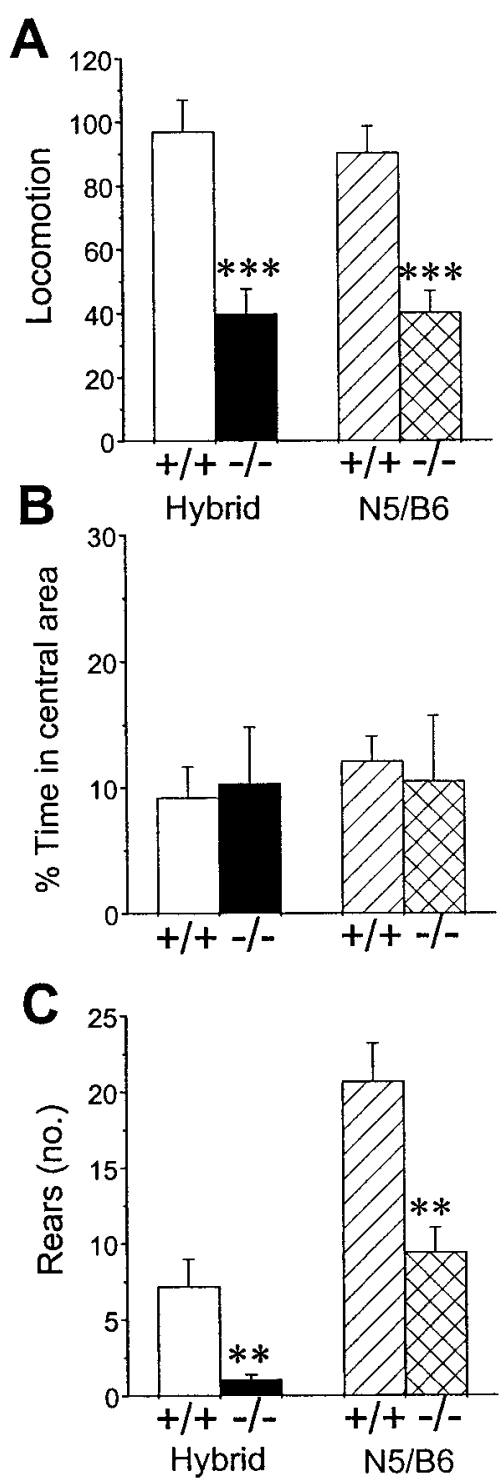

Figure 4. Behavior of wild-type $(+/+)$ and D2L-deficient $(-/-)$ mice in the open-field test, measured within $5 \mathrm{~min}$. $A$, Locomotion (number of squares crossed). $B$, Percentage of time animals spent in the central area. $C$, Total number (no.) of rears displayed within the observed period. All data are expressed as the mean \pm SEM. Asterisks indicate significant differences between $+/+$ and $-/-$ groups at the level of $* * p<0.001$ or $* * * p<0.0001$ (Student's $t$ test). Hybrid represents mice on a hybrid background, and N5/B6 represents mice on a congenic B6 background. Open bars, Hybrid $+/+(n=12)$; solid bars, hybrid $-/-(n=17) ;$ hatched bars, N5/B6 +/+ $(n=14)$; crosshatched bars, N5/B6 -/- $(n=14)$.

\section{D2L-deficient mice exhibit reduced levels of locomotion and rearing}

Because the D2 receptor in the basal ganglia is involved in the regulation of motor functions (Graybiel et al., 1994), we first examined whether D2L-/- mice displayed any alterations in motor behavior. Locomotor activity was assessed using the open-field test. As shown in Figure 4, both locomotion and rearing behavior were significantly reduced in $\mathrm{D} 2 \mathrm{~L}-/-$ mice compared with WT littermates. It is interesting to note that baseline levels of rearing were different between mice with different genetic backgrounds. However, it is well known that different strains of wild-type mice exhibit different degrees of behavioral responses to the same types of tests. The purpose of these studies was to compare mutant mice with wild-type mice on a similar background. There was no significant difference in the amount of time spent in the central area between the two genotypes, suggesting that D2L $-/-$ mice did not show more thigmotaxis (a behavior associated with increased fear)

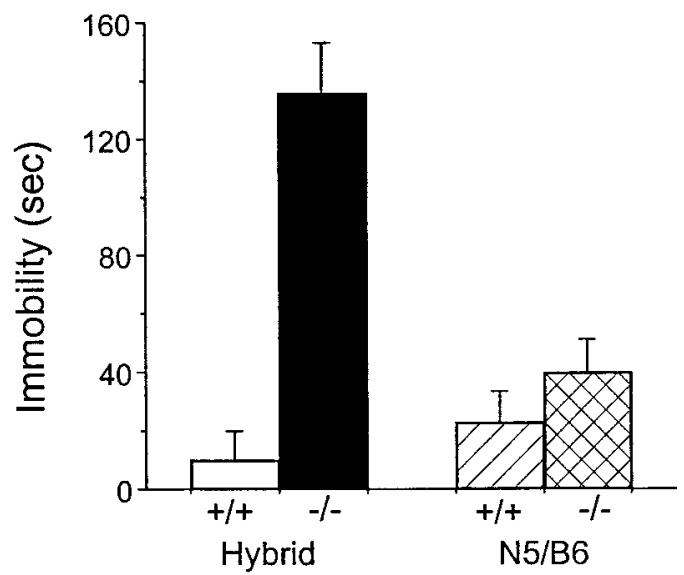

Figure 5. Basal immobility in mice. Basal immobility is expressed as the duration of immobilization (in seconds) in the ring test. The open bar represents the hybrid $+/+(n=12)$, and the solid bar represents the hybrid $-/-(n=17)(p<0.005$, Mann-Whitney test $)$. The hatched bar represents the N5/B6 $+/+(n=13)$, and the crosshatched bar represents the N5/B6 $-/-(n=14)$.

than did WT mice. These results suggest that D2L may have a larger impact on locomotion and rearing.

Spontaneous (or basal) immobility was measured using the ring test. D2L-/- mice on a hybrid background displayed significantly longer periods of immobility than did their WT littermates (Fig. 5). Although the mutant mice on a congenic B6 background showed longer periods of basal immobility than did WT mice, the difference did not reach statistical significance (Fig. 5). One possible explanation for the discrepancy in the immobility between the hybrid $-/-$ and the congenic B6 $-/-$ mice is that the variation of genetic background contributed to the immobility exhibited in the hybrid mutants. Another possibility is that the impact of lacking D2L was greater in animals on a hybrid background.

The reduction in locomotion and rearing behavior and the increased duration of immobility could be interpreted as being caused by an increased state of apprehension, rather than by a deficiency in motor function in the mutant mice. Therefore, we evaluated anxiety behavior using the elevated zero-maze (Konig et al., 1996). As illustrated in Figure 6, there were no significant differences in the percentage of time spent in the open sectors, the general activity, and the number of head dips between mutant and WT mice. In contrast, D2L-/- mice displayed significantly less stretched attend postures than did WT mice. It has been reported that a decrease in stretched attend postures is associated with decreased levels of anxiety (Shepherd et al., 1994). Thus, these results suggested that $\mathrm{D} 2 \mathrm{~L}-1-$ mice did not have increased anxiety as compared with WT mice and may even have reduced anxiety.

We examined the ability of mice to perform the rotarod test, which is widely used to evaluate motor coordination in rodents. The greater the duration of time the animals were able to stay on a rotating rod, the better motor coordination the animals had. As shown in Figure 7, on day 1, D2L-/- mice initially performed this test poorly. However, the performance of $\mathrm{D} 2 \mathrm{~L}-/-$ mice in the subsequent trials was not significantly different from that of WT mice ( $p>0.3$, Mann-Whitney test). On day 2, both WT and mutant mice maintained their ability to perform the rotarod test, learned from the previous day, and there was no significant difference in the time remaining on the rod between WT and D2L-/mice $(p>0.4)$. These results suggested that $\mathrm{D} 2 \mathrm{~L}-/-$ mice were not deficient in the motor coordination measured with the rotarod test. The neurobiological basis of motor coordination measured with the rotarod test may be complex, in that it may involve a large cerebellar component. On the other hand, the locomotor behavior may involve a large basal ganglion component. These reflect two different motor abilities, which are not necessary to be correlated. This is also true for D2-null knock-out mice that displayed reduced 

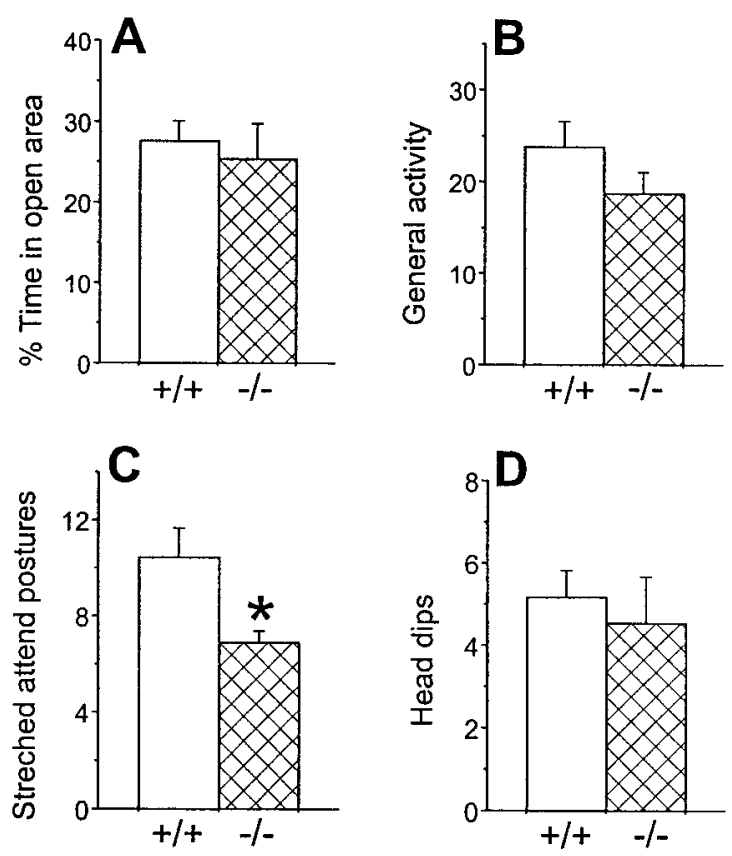

Figure 6. Behavior of mice on a congenic B6 background in the zero-maze test. $A$, Percentage of time that mice spent in open sectors (\% Time in open area). $B$, General activity (i.e., total entries to different sectors). $C$, Number of stretched attend postures displayed by animals. $D$, Number of head dips displayed by animals. Data are presented as the mean \pm SEM. Open bars, $+/+(n=11)$; crosshatched bars, $-/-(n=11)$. There were no significant differences between $+/+$ and $-/-$ mice in either the percent of time in the open area ( $p>0.7$; Student's $t$ test), general activity $(p>0.2)$, or the number of head dips $(p>0.7)$. However, there was a significant difference between $+/+$ and $-/-$ mice in the number of stretched attend postures $(* p<0.02)$.

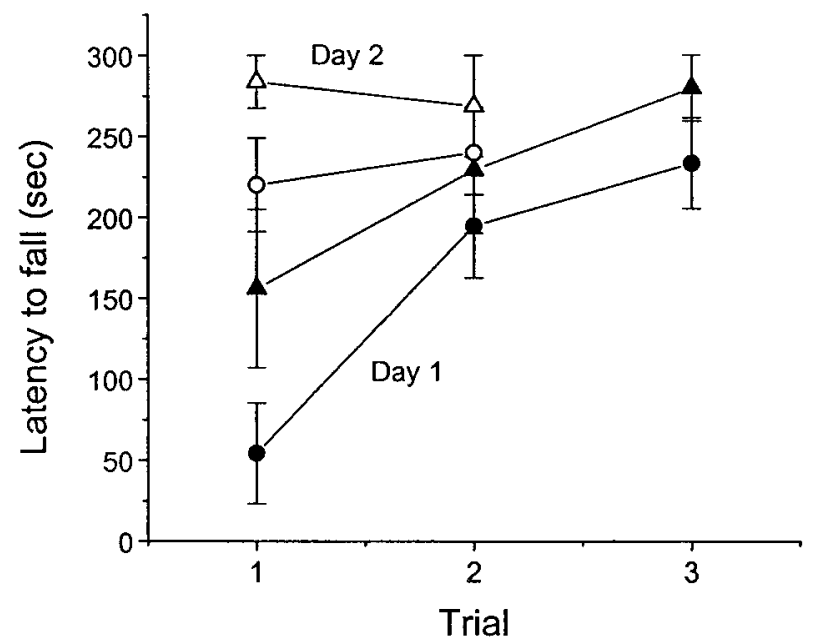

Figure 7. Rotarod performance in wild-type and D2L-/- mice on a congenic B6 background. Data are expressed as means \pm SEM for each trial on 2 consecutive days. For day 1 , solid triangles, $+/+(n=8)$; solid circles, $-/-(n=11)$. The same groups of mice were tested again on day 2 . For day 2 , open triangles, $+1+$; open circles, $-/-$.

locomotor activity and relatively normal motor coordination measured with the rotarod test with training (Kelly et al., 1998).

\section{D2L-deficient mice have reduced sensitivity to haloperidol-induced catalepsy}

To assess the role of D2L in the actions of typical antipsychotic drugs, we examined the effect of haloperidol treatment on catalepsy using the bar test. Haloperidol is representative of a typical antipsychotic drug that elicits the extrapyramidal side effects (EPS) (Seeman and Tallerico, 1998). Catalepsy is considered to be useful
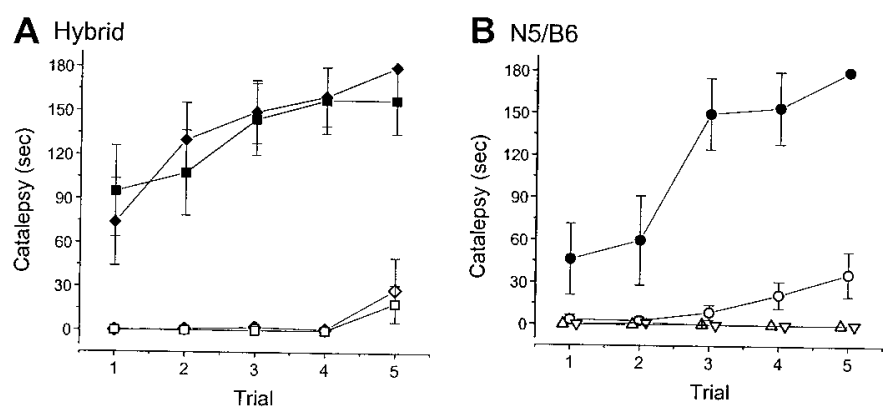

Figure 8. Haloperidol-induced catalepsy in WT $(+/+)$ and D2L-/$(-/-)$ mice, as determined with the bar test. $A$, Haloperidol-induced cataleptic behavior of mice on a hybrid background. Catalepsy is expressed as the duration of immobility (in seconds). Solid squares, $+1+(n=8 ; 0.5$ $\mathrm{mg} / \mathrm{kg}$ haloperidol); open squares, $-/-(n=8 ; 0.5 \mathrm{mg} / \mathrm{kg}$ haloperidol $) ;$ solid diamonds, $+/+(n=9 ; 1.0 \mathrm{mg} / \mathrm{kg}$ haloperidol $) ;$ open diamonds, $-1-(n=$ $8 ; 1.0 \mathrm{mg} / \mathrm{kg}$ haloperidol). Haloperidol induced significantly less catalepsy in $\mathrm{D} 2 \mathrm{~L}-/-$ mice on a hybrid background $(p<0.02$ for $0.5 \mathrm{mg} / \mathrm{kg}$ haloperidol treatment; $p<0.01$ for $1.0 \mathrm{mg} / \mathrm{kg}$ haloperidol treatment, MannWhitney test, two-tailed). $B$, Haloperidol-induced catalepsy of mice on a congenic B6 background. Mice that received haloperidol injection (1.0 $\mathrm{mg} / \mathrm{kg})$ are indicated as follows: solid circles, $+/+(n=7)$; open circles, $-1-$ $(n=9)$. Additional groups of mice received the second vehicle injection instead of drug treatment (i.e., vehicle-vehicle treatment; see Materials and Methods): open triangles, $+/+(n=8)$; open inverted triangles, $-/-(n=8)$. The horizontal scale for mice receiving the second vehicle injection was arbitrarily shifted a little for visibility. The vertical scale represents the accumulative duration of immobility (mean \pm SEM) exhibited by each group of mice. Haloperidol induced significantly less catalepsy in D2L-/mice on a congenic B6 background ( $p<0.01$, Mann-Whitney test). Repeated vehicle treatment did not produce any significant immobility.

for detecting the EPS of antipsychotic drugs, at least for haloperidol (Hoffman and Donovan, 1995). Thirty minutes after intraperitoneal administration of haloperidol, the bar test was conducted. WT mice displayed strong haloperidol-induced catalepsy, whereas D2L-/- mice showed much less catalepsy at the doses of haloperidol tested (Fig. 8). We also observed that just before the bar test ( $\sim 29$ min after haloperidol injection), WT mice showed a large reduction in spontaneous movement in the open field whereas the mutant mice in general showed only a small reduction in this activity.

To confirm further that $\mathrm{D} 2 \mathrm{~L}-/-$ mice were less sensitive to haloperidol, we examined the effects of haloperidol treatment on the locomotor activity of D2L-/- mice. The degree of immobility induced by haloperidol in the open field generally reflected the degree of catalepsy of animals. Thirty minutes after intraperitoneal administration of haloperidol, the open-field test was conducted. Haloperidol dose-dependently inhibited locomotion and rearing behaviors (Fig. 9). In all cases, haloperidol produced significantly less inhibition in $\mathrm{D} 2 \mathrm{~L}-/-$ mice. Taken together, these results suggest that D2L may contribute more to haloperidol-induced catalepsy.

\section{D2L-deficient mice express a functional D2S receptor}

Analysis of genomic DNA and mRNA revealed that the gene structure of the D2S receptor is normal in D2L-/- mice (Fig. 1). Receptor binding (Fig. 3A), immunohistochemical experiments, and receptor autoradiographic analysis (Fig. $2 A$ ) confirmed that the D2S receptor is expressed on the cell surface in the mutant mice. To determine whether $\mathrm{D} 2 \mathrm{~L}-/-$ mice express a functional D2S receptor, we examined the effects of quinpirole, a D2 agonist, on locomotor activity. It has been shown that quinpirole induces an initial suppression of locomotor activity across a range of doses in rodents (Eilam and Szechtman, 1989; Frantz and Hartesveldt, 1995). Ten minutes after injection of quinpirole, locomotor activity was assessed using the open-field test. The quinpirole-elicited dosedependent suppression of locomotion was not significantly different between D2L-/- and WT mice (Fig. 10). These results suggest that the D2S receptor is functional in mutant mice.

Because quinpirole also binds to the D3 receptor, we assessed 

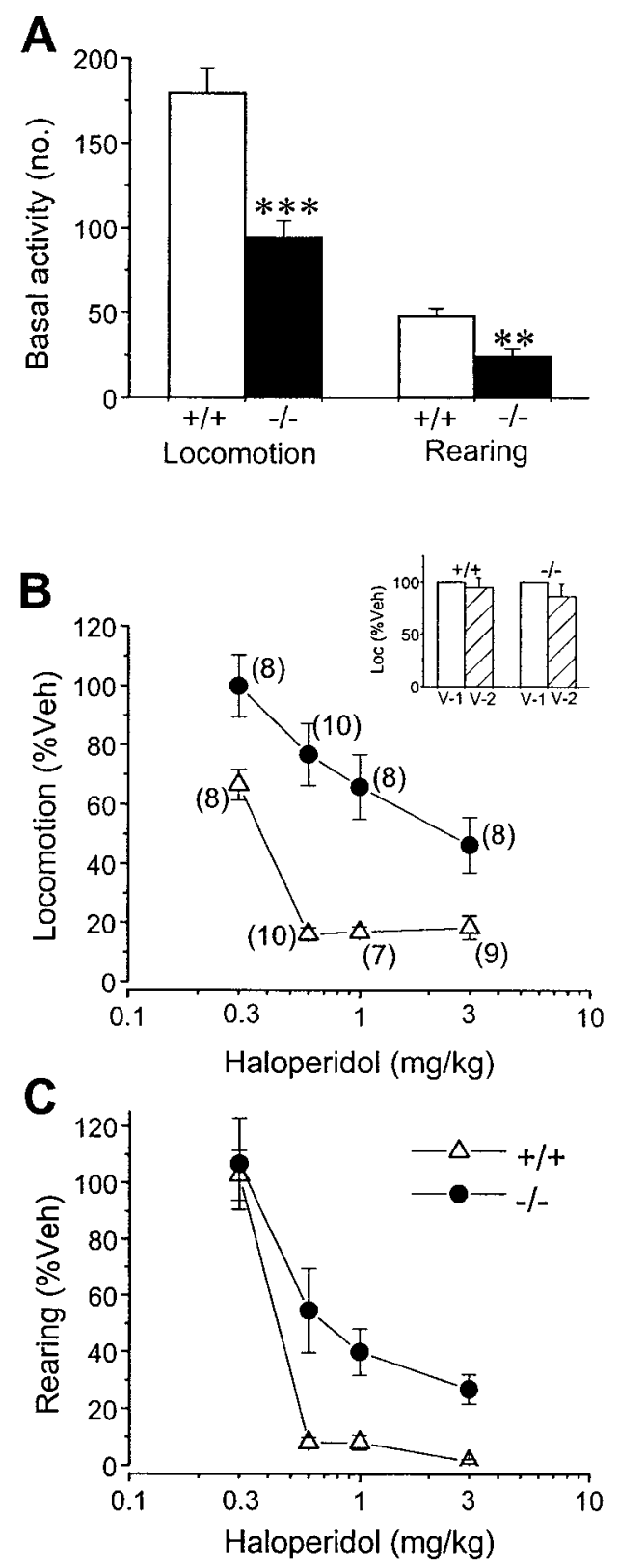

Figure 9. Effects of haloperidol on behaviors of mice on a congenic B6 background in the open-field test, measured within $10 \mathrm{~min}$. A, Basal activity of mice used in this series of experiments (no., number of corresponding activity). In agreement with the results shown in Figure 4 , D2L $-/-$ mice $(-/-)$ displayed significantly lower levels of locomotion $(L o c ; * * *<0.0001)$ and rearing behavior $(* * p<0.001)$ than did WT mice $(+/+)$. $B$, Inhibitory effect of haloperidol on locomotion. The $\mathrm{ED}_{50}$ value of haloperidol for D2L-/- $(2.33 \mathrm{mg} / \mathrm{kg})$ was approximately sixfold higher than that for WT mice $(0.38 \mathrm{mg} / \mathrm{kg})$. $\mathrm{ED}_{50}$ values were assessed with the Prism program. $C$, Inhibitory effect of haloperidol on rearing behavior. Vehicle injection $(\mathrm{Veh})$ was normalized as $100 \%$. All other data were expressed as the percentage of the respective vehicle injection. Haloperidol produced significantly less inhibition in locomotion $\left[F_{(1,63)}=60.96 ; p<0.0001\right.$, two-way ANOVA $]$ and rearing $\left[F_{(1,63)}=\right.$ $11.00 ; p=0.0015]$ in $\mathrm{D} 2 \mathrm{~L}-1-$ than in WT mice. Data shown are the mean \pm SEM. Numbers in parentheses represent numbers of mice. Open triangles, $+/+$; solid circles, $-/-$. The mice used for 0.3 and $0.6 \mathrm{mg} / \mathrm{kg}$ haloperidol injection were the same groups of mice, except that two additional mice for each genotype were also used for $0.6 \mathrm{mg} / \mathrm{kg}$ haloperidol. Different groups of mice were used for $1.0 \mathrm{mg} / \mathrm{kg}$ haloperidol, and different groups of mice were used for $3.0 \mathrm{mg} / \mathrm{kg}$ haloperidol injection. Additional groups of mice $(n=7$ for $+/+; n=8$ for $-/-)$ received repeated vehicle injections; $V-1$ represents the first vehicle treatment, and $V-2$ represents the second vehicle treatment that was given a few days later (see Materials and Methods). Locomotion of $V-1$ was normalized as $100 \%$, and $V$-2 was expressed as a percentage of $V$ - 1 . Inset, $B$, No significant effect on locomotion with repeated vehicle injections $(+/+, V-1$ vs $V-2, p>1.0 ;-/-$, $V-1$ vs $V-2, p>0.2$, Student's $t$ test).

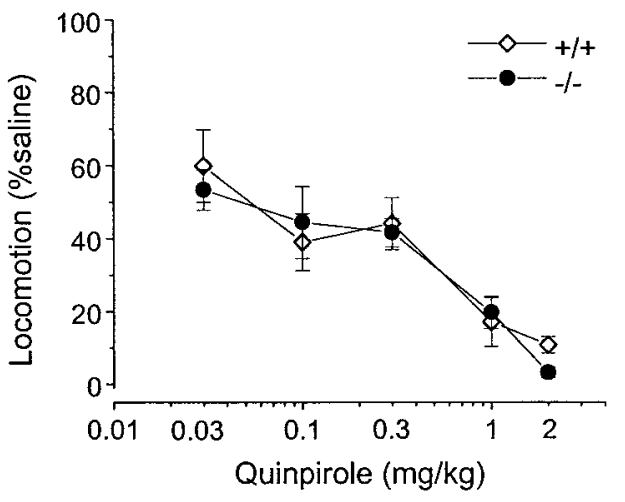

Figure 10. Dose-dependent effect of quinpirole on mice on a congenic B6 background in the open-field test, measured within $10 \mathrm{~min}$. There was no significant difference between D2L $-/-(-/-)$ and $\mathrm{WT}(+/+)$ mice in the quinpirole-induced suppression of locomotor activity $\left[F_{(1,78)}=0.17 ; p=\right.$ 0.6775 , two-way ANOVA]. The responses to quinpirole treatment were expressed as the percentage of saline injection that was normalized to $100 \%$. Six to eight mice of each genotype were used for each dose. Open diamonds, $+/+;$ solid circles, $-/-$.
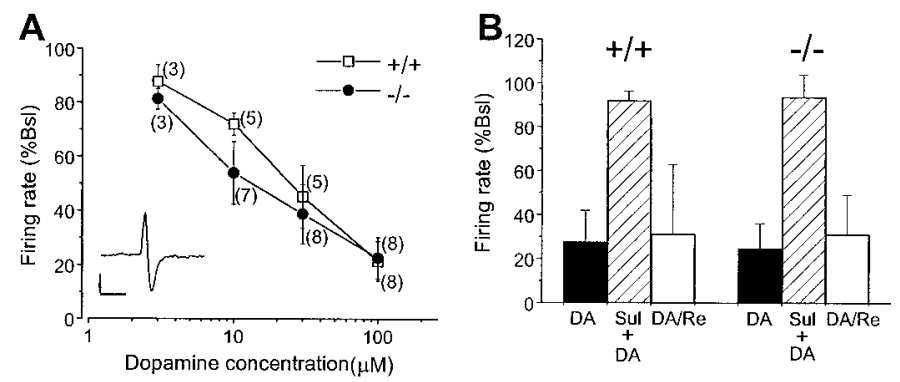

Figure 11. Inhibitory effect of dopamine on the firing rate of SNc neurons and the blockade of dopamine-induced inhibition by sulpiride. A, Doseresponse relationship is shown for dopamine-induced inhibition of the firing rate of SNc neurons from WT ( $n=8$ neurons from $6+/+$ mice) and $\mathrm{D} 2 \mathrm{~L}-/-(n=11$ neurons from $9-/-$ mice $)$. In most cases, at least three doses of DA were tested on the same cells. Data are expressed as the mean \pm SEM with the numbers of neurons represented by each data point indicated in parentheses. The dose-response curves of DA inhibition are not significantly different between $+/+$ and $-/-$ mice $\left[F_{(153)}=1.19 ; p>0.28\right.$, two-way ANOVA]. Inset, A sample trace of extracellular spike is shown. Calibration: $0.5 \mathrm{mV}, 5 \mathrm{msec}$. Basal firing rate $(B s l)$ was normalized as $100 \%$. B Sulpiride $(S u l)$ antagonized the effects of DA. DA $(100 \mu \mathrm{M})$ inhibited the SNc neuronal firing (solid bars). (-)-Sulpiride $(1 \mu \mathrm{M})$ primarily attenuated or completely blocked the effect of DA (hatched bars). Data shown represent $n=3$ neurons from two $+/+$ mice and $n=5$ neurons from five $-/-$ mice. Sulpiride by itself elicited small increases in firing rate $(4.4 \pm 2.2 \%$ for $+/+; 7.7 \pm 4.0 \%$ for $-/-)$. In some cells, dopamine was applied again after $1-2 \mathrm{hr}$ of washing out sulpiride $(n=2$ from $2+/+$ mice; $n=3$ from $3-/-$ mice). The inhibitory effect of DA was primarily restored (DA/Re; open bars).

the electrophysiological effect of dopamine on the neurons of the zona compacta of the substantia nigra to determine further whether D2L-/- mice express a functional D2S receptor. It has been well documented that dopamine exerts an inhibitory effect on SNc dopaminergic neurons and that this effect is mediated specifically by the D2 receptor (Bunney et al., 1973; Pinnock, 1984; Sanghera et al., 1984; Lacey et al., 1987; Yamaguchi et al., 1996; Mercuri et al., 1997). Spontaneous firing of SNc neurons was recorded extracellularly in brain slices (Wang and Aghajanian, 1987, 1989). Dopamine (3-100 $\mu \mathrm{M})$, applied by superfusion, elicited a similar concentration-dependent reduction in the spontaneous firing rate of SNc neurons from both WT and D2L $-/-$ mice (Fig. 11A). There was also no significant difference in the basal firing rates of SNc neurons between WT $(3.60 \pm 0.37 \mathrm{~Hz} ; n=8)$ and mutant $(3.55 \pm 0.35 \mathrm{~Hz} ; n=11)$ mice $(p>0.93)$. The electrophysiological characteristics of dopaminergic neurons recorded extracellularly in SNc from both genotypes were indistinguishable. The inhibitory effect of dopamine $(100 \mu \mathrm{M})$ on the 

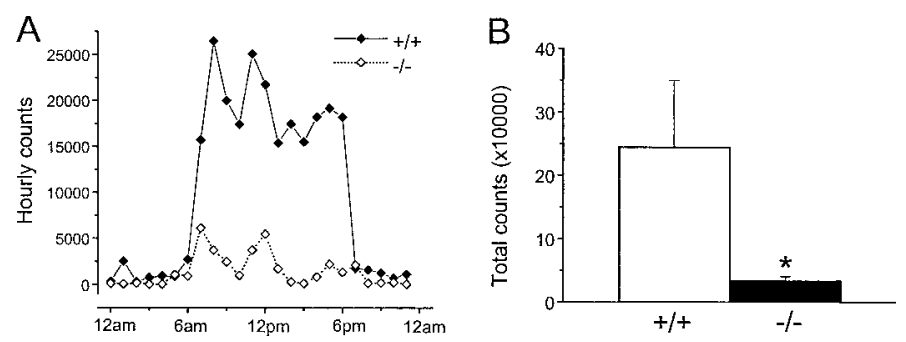

Figure 12. Motor activity in the home cage. $A$, The activity of D2L-/$(-/-;$ open diamonds; $n=7)$ and WT $(+/+;$ solid diamonds; $n=6)$ on a congenic B6 background in the home cage during a $24 \mathrm{hr}$ period. Data are expressed as average counts during each $1 \mathrm{hr}$ time block. $B$, The total activity of animals over $24 \mathrm{hr}$ in the home cage. Data are expressed as the mean \pm SEM. There was a significant difference in activity between $-/-$ (open bar) and $+1+$ (solid bar) mice $(* p<0.05$, Student's $t$ test).

spontaneous firing of SNc neurons was markedly attenuated or completely blocked by the inclusion of $1 \mu \mathrm{M}(-)$-sulpiride, a D2 receptor antagonist (Fig. $11 B$ ). These studies further demonstrated that D2S was fully functional in $\mathrm{D} 2 \mathrm{~L}-/-$ mice and suggest that D2S functions approximately equally well as D2L as an impulsemodulating autoreceptor in the SNc (for review, see Wolf and Roth, 1987). These results provide additional evidence that the total D2 receptor density is similar between mutant and WT mice.

\section{D2L-deficient mice exhibit reduced motor activity in the home cage}

To study further the motor behavior of D2L-/- mice, we examined the spontaneous basal motor activity of animals in their home cages during the $24 \mathrm{hr}$ circadian cycle. The activity of D2L-/mice was reduced in the diurnal as well as the nocturnal period, particularly during the diurnal period (Fig. 12); however, the circadian pattern of the mutant mice was not different from that of WT mice. These results suggest that the reduction in locomotor activity of $\mathrm{D} 2 \mathrm{~L}-/-$ mice in a novel environment is caused, at least partially, by a general decrease in motor activity.

\section{DISCUSSION}

We found that D2L-/- mice (expressing exclusively D2S) displayed deficiencies in locomotion and rearing behavior but not in anxiety, motor coordination measured with the rotarod test, and impulse-modulating autoreceptor function. Interestingly, D2L-/mice were less sensitive to haloperidol-induced catalepsy and locomotor inhibition. However, D2L-/- and WT mice were approximately equally sensitive to quinpirole-induced initial locomotor suppression. These results have several implications: (1) that D2L might have a bigger impact on certain types of motor functions, (2) that blockade of D2L might contribute more than blockade of D2S to the extrapyramidal side effects (or parkinsonism) that are commonly associated with typical antipsychotic drugs, and (3) that the functions of these two isoforms were not dependent on the formation of receptor heterodimers. Note that our findings could not have been achieved using pharmacological methods, because no D2 isoform-selective compounds are available.

The behavioral phenotypes observed in $\mathrm{D} 2 \mathrm{~L}-/-$ mice were not attributable to an overall reduction in D2 receptor density. No significant differences were observed between the mutant and WT mice in either total striatal D2 mRNA, as measured by Northern blot, or D2 receptor density, as measured by $\left[{ }^{3} \mathrm{H}\right] \mathrm{YM}-09151-2$ binding and D2-mediated electrophysiological responses. These measurements indicated a compensatory increase in D2S expression levels in mice lacking D2L.

We further demonstrated that the D2S receptor is functional in D2L $-/-$ mice, using both behavioral and physiological assays. The inhibitory effect of DA on SNc neurons is mediated specifically by D2 because it is completely blocked by D2 antagonists (Bunney et al., 1973; Pinnock, 1984; Sanghera et al., 1984; Lacey et al., 1987) and it is absent in D2-null knock-out mice (Yamaguchi et al., 1996; Mercuri et al., 1997). The inhibitory effect of DA on SNc neurons is not mediated by D3 or D4, because the effect of DA is intact in D3 knock-out mice (Koeltzow et al., 1998) and there is no detectable D4 expression in SN (Bouthenet et al., 1991). This effect is also not mediated by D1, because a specific D1 antagonist does not block the DA effect (Lacey et al., 1987).

Unlike D2-null knock-out mice that do not show a response to 2 $\mathrm{mg} / \mathrm{kg}$ quinpirole (Kelly et al., 1998), D2L-/- and WT mice had similar sensitivities to quinpirole. It has been established that low doses of D2 agonists (e.g., quinpirole) suppress locomotor activity in rodents (Eilam and Szechtman, 1989). This effect is thought to be mediated by stimulation of DA autoreceptors located in the midbrain (Aghajanian and Bunney, 1977; White and Wang, 1984). Higher doses of D2 agonists produce biphasic effects on locomotion, initially decreasing and later increasing locomotor activity (Eilam and Szechtman, 1989; Frantz and Hartesveldt, 1995). It has been suggested that the initial suppression of locomotion by higher doses of D2 agonists is also mediated by autoreceptors. Our results are consistent with the idea that the initial suppression of locomotor activity induced by quinpirole is mediated by D2 autoreceptors, because this effect was correlated with our electrophysiological data showing that dopamine had inhibitory effects on SNc neurons.

Some of the behavioral changes such as locomotion may be primarily dependent on the nucleus accumbens, whereas some such as catalepsy may be dependent on both the caudate-putamen and the nucleus accumbens. In all references to "striatum" in this paper, we refer to the entire striatum, i.e., the dorsal striatum (including the caudate nucleus and putamen) and the ventral striatum (including the nucleus accumbens, olfactory tubercle, and the ventral part of caudate-putamen). It is likely that both the nigrostriatal and mesolimbic dopamine systems are involved in the behavioral changes studied here.

Are the phenotypic behaviors shown here caused by the lack of D2L or by the upregulation of D2S? We favor the former possibility for the following reasons: (1) If hypolocomotion observed in the mutant is the consequence of the upregulation of D2S, then D2S would have a functional effect opposite that of D2L. Studies in transfected cell lines have shown that the two isoforms of D2 receptor either both inhibit adenylyl cyclase, although to a different degree, or are both coupled to different $\mathrm{G}_{\mathrm{i}}$-proteins (Dal Toso et al., 1989; Senogles, 1994; Picetti et al., 1997). This suggests that these two alternatively spliced variants and highly structurally homologous proteins function in a complementary and synergistic manner, rather than an antagonistic one. (2) The reduced spontaneous movement observed in $\mathrm{D} 2 \mathrm{~L}-/-$ mice resembles the phenotypic behavior reported in D2-null knock-out mice (which are deficient in both D2 isoforms) (Baik et al., 1995; Yamaguchi et al., 1996; Kelly et al., 1998). In particular, the locomotor activity of D2L $-/-$ mice on a congenic B6 background was $\sim 50 \%$ lower than that of WT mice, which is comparable with the degree of reduction in locomotion observed in D2-null knock-outs on a similar genetic background (Kelly et al., 1998). This suggests that the reduced locomotor activity seen in D2L-/ - mice is mainly caused by the absence of D2L. (3) As illustrated in Figure 9, haloperidol produced a dose-dependent inhibition of locomotion and rearing behaviors of both WT and D2L-/-, although to a much lesser degree in $\mathrm{D} 2 \mathrm{~L}-/-$ mice. This further suggests that D2S is unlikely to have effects on locomotor activity that oppose those of D2L; otherwise, the reverse behavioral phenotype would be predicted. Could the function of D2S be dependent on the presence of D2L? We observed that the effects of quinpirole, dopamine, and sulpiride were intact in D2L-/- mice. This suggests that D2S can function independently, at least with respect to drug treatment. Taken together, the evidence suggests that the phenotypic behaviors examined here are likely attributed to the lack of D2L in the mutant mice. We cannot, however, exclude the possibility that the upregulation of D2S might have effects on other animal behaviors that were not examined in this study. In the future, it will be of interest to compare WT with $\mathrm{D} 2 \mathrm{~S}-/-$ mice (when these animals become available) and to compare D2L-/- with D2S $-/-$. Such studies will further improve our understanding of the specific functions of 
each isoform. The profound phenotypic differences we characterized in this study, comparing D2L-/- with WT mice, represent an important and promising first step in defining unique functional roles of individual D2 isoforms in the CNS.

Are some behavioral changes caused by the compensatory changes in the D1 receptor? At this stage, we cannot completely exclude a possible compensatory change in the D1 receptor in D2L-/- mice. However, our receptor binding data indicate that the D1 receptor sites and affinity remain unchanged in the mutant mice. In addition, it has been reported that there is no detectable upregulation in other components of central dopaminergic systems in D2-null knock-out mice and a possible change in the D1 receptor cannot be a major adaptation mechanism (Baik et al., 1995; Kelly et al., 1998). If the D1 receptor has not been shown to be a major compensatory mechanism in D2-null knock-out mice in which the entire D2 gene was deleted, it is unlikely that the potential alteration in the D1 receptor would be a major compensatory mechanism in the more subtle D2L-/- mutant mice. In the future, it will be of interest to study the functional interaction between the D1 and D2L or D2S receptor. It is possible that the D1 receptor system per se may not be changed in our mutant; however, the interaction between D2S and D1 may differ from that of D2L and D1.

The D2 receptor system has been implicated in both schizophrenia and Parkinson's disease (Carlsson and Carlsson, 1990; Graybiel, 1995; Jaber et al., 1996). Levodopa (a DA precursor) and D2 agonists effectively relieve the motor symptoms of Parkinson's disease but can also elicit psychosis in parkinsonian patients (Snyder, 1972). D2 receptor antagonists alleviate the psychotic symptoms of schizophrenia. However, some D2 antagonists (e.g., haloperidol) elicit adverse extrapyramidal side effects that are attributed, at least partially, to blockade of D2 in the striatum (Seeman and Tallerico, 1998). We observed that unlike the effects of quinpirole and dopamine, haloperidol produced significantly less inhibition of motor activity in $\mathrm{D} 2 \mathrm{~L}-/-$ mice. The results suggest that D2L may contribute more than D2S to haloperidolinduced catalepsy. Because catalepsy is considered to be useful for detecting the EPS of antipsychotic drugs, at least for some drugs (Hoffman and Donovan, 1995), this raises the possibility that D2L might contribute more to the development of EPS induced by haloperidol. These findings might lead to a potential new way for designing improved antipsychotic drugs. For example, an antipsychotic drug with lower affinity for D2L than for D2S might have increased therapeutic efficacy with fewer EPS. The diminished effects of haloperidol in D2L-/- mice could result from its different affinities for individual D2 isoforms and/or from differential intracellular coupling mechanisms of D2L versus D2S. Because the $\mathrm{D} 2$ receptor system has been reported to link to multiple signal transduction pathways, including that of cAMP, $\mathrm{Ca}^{2+}$, and $\mathrm{IP}_{3}$ (Civelli et al., 1993; Picetti et al., 1997), there is a possibility that D2L and D2S may couple to distinct signaling pathways in addition to those they share. Thus, it is possible that a more effective approach to develop improved drugs may be to target intervention at the postreceptor levels (e.g., intracellular signaling pathways). Taken together, our studies demonstrated that the D2L - / - mouse displayed an interesting behavioral phenotype and provided novel information concerning the potential functional roles of D2L and D2S. In the future, it will be of considerable interest to study other aspects of this mutant mouse.

Our findings demonstrated, for the first time, that the D2L and D2S receptors may have differential functional roles in the CNS. These studies showed that despite a compensatory upregulation of the D2S isoform in D2L-/- mice, D2S could not substitute in certain functions of D2L. On the basis of these findings, we propose that the two D2 isoforms may have different roles in motor and cognitive functions. Thus, understanding the specific functions of D2L and D2S may provide novel information toward potentially developing better pharmacological agents for the treatment of disorders of central dopaminergic systems, including schizophrenia and Parkinson's disease.

\section{REFERENCES}

Aghajanian GK, Bunney BS (1977) Dopamine autoreceptors' pharmacological characterization by microiontophoretic single cell recording studies. Naunyn Schmiedebergs Arch Pharmacol 297:1-7.

Baik J-H, Picetti R, Salardi A, Thirlet G, Dierich A, Depaulis A, Le Meur M, Borrelli E (1995) Parkinson-like locomotor impairment in mice lacking dopamine D2 receptors. Nature 5:424-428.

Banbury Conference on Genetic Background in Mice (1997) Mutant mice and neuroscience: recommendations concerning genetic background. Neuron 19:755-759.

Boundy VA, Lu L, Molinoff PB (1996) Differential coupling of rat D2 dopamine receptor isoforms expressed in Spodoptera frugiperda insect cells. J Pharmacol Exp Ther 276:784-794.

Bouthenet ML, Souil E, Martres MP, Sokoloff P, Giros B, Schwartz JC (1991) Localization of dopamine D3 receptor mRNA in the rat brain using in situ hybridization histochemistry: comparison with dopamine D2 receptor mRNA. Brain Res 564:203-219.

Bunney BS, Walters JR, Roth RH, Aghajanian GK (1973) Dopaminergic neurons: effect of antipsychotic drugs and amphetamine on single cell activity. J Pharmacol Exp Ther 185:560-571.

Bunzow JR, Van Tol HHM, Grandy DK, Albert P, Salon J, Christie M, Machida CA, Neve KA, Civelli O (1988) Cloning and expression of a rat D2 dopamine receptor cDNA. Nature 336:783-787.

Carlsson M, Carlsson A (1990) Interactions between glutamatergic and monoaminergic systems within the basal ganglia-implications for schizophrenia and Parkinson's disease. Trends Neurosci 13:274-276.

Chio CL, Hess GF, Graham RS, Huff RM (1990) A second molecular form of D2 dopamine receptor in rat and bovine caudate nucleus. Nature 343:266-269.

Civelli O, Bunzow JR, Grandy DK (1993) Molecular diversity of the dopamine receptors. Annu Rev Pharmacol Toxicol 32:281-307.

Dal Toso R, Sommer B, Ewert M, Herb A, Pritchett DB, Bach A, Shivers BD, Seeburg PH (1989) The dopamine D2 receptor: two molecular forms generated by alternative splicing. EMBO J 8:4025-4034.

Eilam D, Szechtman H (1989) Biphasic effect of D2 agonist quinpirole on locomotion and movements. Eur J Pharmacol 161:151-157.

Franklin KBJ, Paxinos G (1996) The mouse brain in stereotaxic coordinates. New York: Academic.

Frantz KJ, Hartesveldt CV (1995) Sulpiride antagonizes the biphasic locomotor effects of quinpirole in weanling rats. Psychopharmacology (Berl) 119:299-304.

Giros B, Sokoloff P, Martres MP, Riou JF, Emorine LJ, Schwartz JC (1989) Alternative splicing directs the expression of two D2 dopamine receptor isoforms. Nature 342:923-926.

Grace AA, Bunney BS (1983) Intracellular and extracellular electrophysiology of nigral dopaminergic neurons. 1. Identification and characterization. Neuroscience 10:301-315.

Graybiel AM (1995) The basal ganglia. Trends Neurosci 18:60-62.

Graybiel AM, Aosaki T, Flaherty AW, Kimura M (1994) The basal ganglia and adaptive motor control. Science 265:1826-1831.

Guiramand J, Montmayeur J-P, Ceraline J, Bhatia M, Borrelli E (1995) Alternative splicing of the dopamine D2 receptor directs specificity of coupling to G-proteins. J Biol Chem 270:7354-7358.

Hoffman DC, Donovan H (1995) Catalepsy as a rodent model for detecting antipsychotic drugs with extrapyramidal side effect liability. Psychopharmacology (Berl) 120:128-133.

Hornykiewicz O (1966) Metabolism of brain dopamine in human parkinsonism: neurochemical and clinical aspects. In: Biochemistry and pharmacology of the basal ganglia (Costa E, Cote LJ, Yahr MD, eds), pp 171-181. New York: Raven.

Jaber M, Robinson SW, Missale C, Caron MG (1996) Dopamine receptors and brain function. Neuropharmacology 35:1503-1519.

Jaskiw GE, Weinberger DR (1992) Dopamine and schizophrenia-a cortically corrective perspective. Semin Neurosci 4:179-188.

Jones BJ, Roberts DJ (1968) The quantitative measurement of motor incoordination in naïve mice using an accelerating Rota-rod. J Pharm Pharmacol 20:302-304.

Kelly MA, Rubinstein M, Asa SL, Zhang G, Saez C, Bunzow JR, Allen RG, Hnasko R, Ben Jonathan N, Grandy DK, Low MJ (1997) Pituitary lactotroph hyperplasia and chronic hyperprolactinemia in dopamine D2 receptor-deficient mice. Neuron 19:103-113.

Kelly MA, Rubinstein M, Phillips TJ, Lessov CN, Burkhart-Kasch S, Zhang G, Bunzow JR, Fang Y, Gerhardt GA, Grandy DK, Low MJ (1998) Locomotor activity in D2 dopamine receptor deficient mice is determined by gene dosage, genetic background, and developmental adaptations. J Neurosci 18:3470-3479.

Koeltzow TE, Xu M, Cooper DC, Hu X-T, Tonegawa S, Wolf ME, White FJ (1998) Alterations in dopamine release but not dopamine autoreceptor function in dopamine D3 receptor mutant mice. J Neurosci 18:2231-2238.

Konig M, Zimmer AM, Steiner H, Holmes PV, Crawley JN, Brownstein MJ, Zimmer A (1996) Pain responses, anxiety and aggression in mice deficient in pre-proenkephalin. Nature 383:535-538.

Koob GF, Sanna PP, Bloom FE (1998) Neuroscience of addiction. Neuron 21:467-476.

Kung M-P, Chumpradit S, Frederick D, Garner S, Burris KD, Molinoff PB, Kung HF (1994) Characterization of binding sites of $\left[{ }^{125} \mathrm{I}\right] \mathrm{R}(+)$ trans- 
7-OH-PIPAT in rat brain. Naunyn Schmiedebergs Arch Pharmacol 350:611-617.

Lacey MG, Mercuri NB, North RA (1987) Dopamine acts on D2 receptors to increase potassium conductance in neurones of the rat substantia nigra zona compacta. J Physiol (Lond) 392:397-416.

Mack KJ, Todd RD, O’Malley KL (1991) The mouse dopamine D2A receptor gene: sequence homology with the rat and human genes and expression of alternative transcripts. J Neurochem 57:795-801.

Mercuri NB, Saiardi A, Bonci A, Picetti R, Calabresi P, Bernardi G, Borrelli E (1997) Loss of autoreceptor function in dopaminergic neurons from dopamine D2 receptor deficient mice. Neuroscience 79:323-327.

Monsma Jr FJ, McVittie LD, Gerfen CR, Mahan LC, Sibley DR (1989) Multiple D2 dopamine receptors produced by alternative RNA splicing. Nature 342:926-929.

Nestler EJ, Aghajanian GK (1997) Molecular and cellular basis of addiction. Science 278:58-63.

Neve KA, Neve RL, Fidel S, Janowsky A, Higgins GA (1991) Increased abundance of alternatively spliced forms of D2 dopamine receptor mRNA after denervation. Proc Natl Acad Sci USA 88:2802-2806.

O'Dowd BF, Hnatowich M, Regan JW, Leader WM, Caron MG, Lefkowitz RJ (1988) Site directed mutagenesis of the cytoplasmic domains of the human beta 2-adrenergic receptor. Localization of regions involved in G protein-receptor coupling. J Biol Chem 263:15985-15992.

Pertwee RG (1972) The ring test: a quantitative method for assessing the "cataleptic" effect of cannabis in mice. Br J Pharmacol 46:753-763.

Picetti R, Saiardi A, Samad TA, Bozzi Y, Baik J-H, Borelli E (1997) Dopamine D2 receptors in signal transduction and behavior. Crit Rev Neurobiol 11:121-142.

Pinnock RD (1984) The actions of antipsychotic drugs on dopamine receptors in the rat substantia nigra. Br J Pharmacol 81:631-635.

Sanghera MK, Trulson ME, German DC (1984) Electrophysiological properties of mouse dopamine neurons: in vivo and in vitro studies. Neuroscience 12:793-801.

Seeman P, Tallerico T (1998) Antipsychotic drugs which elicit little or no Parkinsonism bind more loosely than dopamine to brain D2 receptors, yet occupy high levels of these receptors. Mol Psychiatry 3:123-134.

Senogles SE (1994) The D2 dopamine receptor isoforms signal through distinct $G_{i \alpha}$ proteins to inhibit adenylyl cyclase. J Biol Chem 269:23120-23127.

Shepherd JK, Grewal SS, Fletcher A, Bill DJ, Dourish CT (1994) Behavioural and pharmacological characterization of the elevated "zero-maze" as an animal model of anxiety. Psychopharmacology (Berl) 116:56-64.

Sibley DR, Monsma Jr FJ, Shen Y (1993) Molecular neurobiology of dopaminergic receptors. Int Rev Neurobiol 35:391-415.

Silva AJ, Stevens CF, Tonegawa S, Wang Y (1992) Deficient hippocampal long-term potentiation in $\alpha$-calcium-calmodulin kinase II mutant mice. Science 257:201-204.
Snyder SH (1972) Catecholamines in the brain as mediators of amphetamine psychosis. Arch Gen Psychiatry 27:169-179.

Stevens CF, Wang Y (1994) Changes in reliability of synaptic function as a mechanism for plasticity. Nature 371:704-707.

Ushijima I, Mizuki Y, Yamada M (1995) Alteration of cataleptic responses induced by dopamine receptor antagonists after chronic cocaine administration in mice. Eur J Pharmacol 285:55-59.

Vessotskie JM, Kung M-P, Chumpradit S, Kung HF (1997a) Characterization of $\left[{ }^{125} \mathrm{I}\right] \mathrm{S}(-) 5-\mathrm{OH}$-PIPAT binding to dopamine D2-like receptors expressed in cell lines. Neuropharmacology 36:999-1007.

Vessotskie JM, Kung M-P, Chumpradit S, Kung HF (1997b) Quantitative autoradiographic studies of dopamine D3 receptors in rat cerebellum using [ $\left.{ }^{125} \mathrm{I}\right] \mathrm{S}(-)$ 5-OH-PIPAT. Brain Res 778:89-98.

Vile JM, D'Souza UM, Strange PG (1995) $\left[{ }^{3} \mathrm{H}\right]$ Nemanopride and $\left[{ }^{3} \mathrm{H}\right]$ spiperone label equivalent numbers of D2 and D3 dopamine receptors in a range of tissues and under different conditions. J Neurochem 64:940-943.

Wang Y, Aghajanian GK (1987) Excitation of locus coeruleus neurons by an adenosine $3^{\prime}, 5^{\prime}$ cyclic monophosphate-activated inward current: extracellular and intracellular studies in rat brain slices. Synapse 1:481-487.

Wang Y, Aghajanian GK (1989) Excitation of locus coeruleus neurons by vasoactive intestinal peptide: evidence for a G-protein mediated inward current. Brain Res 500:107-118.

Wang Y, Aghajanian GK (1990) Excitation of locus coeruleus neurons by vasoactive intestinal peptide: role of cAMP and protein kinase A. J Neurosci 10:3335-3343.

White FJ, Wang RY (1984) Pharmacological characterization of dopamine autoreceptors in the rat ventral tegmental area: microiontophoretic studies. J Pharmacol Exp Ther 231:275-280.

Wolf ME, Roth RH (1987) Dopamine autoreceptors. In: Dopamine receptors (Creese I, Fraser CM, eds), pp 45-96. New York: Liss.

Xu M, Moratalla R, Gold LH, Hiroi N, Koob GF, Graybiel AM, Tonegawa S (1994) Dopamine D1 receptor mutant mice are deficient in striatal expression of dynorphin and in dopamine mediated behavioral responses. Cell 79:729-742.

Xu R, Guan XM, Wang CY (1996) Influence of electroacupuncture and capsaicin treatment on AChE activity and $\left[{ }^{3} \mathrm{H}\right]-\mathrm{QNB}$ binding sites in the spinal dorsal horn. Chen Tzu Yen Chiu 21:47-51.

Yamaguchi H, Aiba A, Nakamura K, Nakao K, Sakagami H, Goto K, Kondo H, Katsuki M (1996) Dopamine D2 receptor plays a critical role in cell proliferation and proopiomelanocortin expression in the pituitary. Genes Cells 1:253-268.

Zhang G, Lagrange AH, Ronnekleiv OK, Kelly MJ (1996) Tolerance of hypothalamic $\beta$ endorphin neurons to $\mu$-opioid receptor activation following chronic morphine treatment. J Pharmacol Exp Ther 277: $551-558$. 